\title{
Analisis Pemodelan Struktur Konstruksi Kapal Ikan Bambu Laminasi Kapasitas 20 GT
}

\author{
Ridho Priangoro dan Heri Supomo \\ Departemen Teknik Perkapalan, Fakultas Teknologi Kelautan, Institut Teknologi Sepuluh Nopember (ITS) \\ e-mail: hsupomo@na.its.ac.id
}

\begin{abstract}
Abstrak-Penelitian kelayakan laminasi Bambu Betung sebagai material utama membangun kapal ikan terus-menerus dikembangkan di Indonesia. Bambu sebagai material orthotropik mempunyai tiga sumbu arah serat, hal ini dapat mempengaruhi distribusi beban yang diterima oleh konstruksi kapal. Beberapa penelitian sebelumnya telah dilakukan untuk mengetahui kekuatan mekanis bambu laminasi, namun hanya arah serat longitudinal. Sehingga penelitian arah serat radial dan tangential perlu dilakukan untuk mengetahui sifat mekanis laminasi Bambu Betung secara keseluruhan dalam segi kekuatan konstruksi kapal ikan. Sifat mekanis laminasi bambu Betung didapatkan dengan melakukan pengujian uji tarik dan tekuk berdasarkan standar ASTM D3500 untuk uji tarik dan ASTM D3043 sebagai standar uji tekuk. Setelah didapatkan nilai kuat tarik dan tekuk maka dilakukan perhitungan ukuran konstruksi berdasarkan rule Biro Klasifikasi Indonesia untuk mendapatkan ukuran konstruksi kapal ikan dengan kapasitas 20GT Pengujian aspek kekuatan konstruksi kapal dilakukan dengan pemodelan struktur menggunakan pendekatan Finite Element Method (FEM). Hasil dari pemodelan struktur menunjukkan distribusi tegangan yang diterima oleh seluruh bagian konstruksi yang terdapat pada kapal Hasil pengujian menunjukkan nilai kuat tarik variasi arah radial sebesar 51,15 MPa, nilai kuat tarik arah tangential sebesar 65,60 MPa, dan nilai kuat tekuk variasi arah tangential sebesar 124,95 MPa., Hasil running pemodelan struktur menunjukkan beban terbesar yang diterima oleh kapal yaitu sebesar 27,60 Mpa. Setelah melakukan analisis hot spot bagian gading kapal yang mendapat stress terbesar yaitu pada bagian bottom buritan kapal.
\end{abstract}

Kata Kunci-bambu betung, kapal ikan 20GT, model struktur konstruksi, sifat mekanik lateral.

\section{PENDAHULUAN}

$\mathrm{K}$ APAL perikan yang tersebar di Indonesia umumnya menggunakan kayu sebagai bahan utama pembangunan, kelangkaan kayu jati tersebut mendorong para praktisi untuk meneliti bahan alternatif pengganti kayu. Penelitian yang dilakukan membahas mengenai kelayakan bambu Betung (Dendrocalamus Asper) sebagai bahan alternatif pengganti kayu sebagai bahan utama dalam pembangunan kapal ikan masih terus menerus dilakukan. Sesuai dengan pembebanan yang diberikan kepada kapal, arah gaya yang bekerja pada beberapa komponen konstruksi meliputi radial, longitudinal dan tangential. Meskipun gaya arah tangential yang timbul karena respon akibat gaya sebuah konstruksi kapal relatif kecil, namun hal ini perlu dihitung secara keseluruhan pada penampang melintang kapal. Dimana terdapat persyaratan bahwa dengan beban dinamik gelombang, tegangan yang terjadi pada sebuah konstruksi tidak boleh melibihi $40 \%$ kekuatan lentur atau 30\% kekuatan tarik bahan pembuatan kapal [1].

Material bambu laminasi ini memiliki sifat dan karakter yang sama sehingga mampu menggantikan material kayu yang selama ini digunakan. Sifat dan karakter tersebut meliputi sifat terhadap beban diam (static loading) dan beban bergerak (dinamic loading). Beban ini adalah gaya yang bekerja pada kapal terutama pada struktur utamanya adalah beban dinamis. Dengan diketahui karakter kapal kayu dan sifat mekanis dari bambu laminasi, maka akan didapat standar kekuatan dan standar ukuran material laminasi untuk struktur kapal kayu. Penelitian mengenai kekuatan kapal bambu laminasi dilakukan analisis dengan menggunakan metode elemen hingga.

Suatu material dapat dikatakan sebagai material isotropic apabila material tersebut memiliki sifat mekanik yang sama pada semua sumbu yang saling berpotongan (axis). Sedangkan material orthotropic memiliki sifat mekanik yang berbeda dan independen pada 3 (tiga) arah perpotongan axis, yakni axial, radial dan tangential. Sifat material orthotropic tergantung pada arah dimana perhitungan dilakukan [2].

Penelitian sebelumnya sudah dilakukan untuk mendapatkan sifat mekanis bambu Betung pada arah memanjang atau longitudinal. Karena bambu laminasi ini termasuk material ortotropik (orthotropic) maka muncul gagasan untuk melakukan penelitian sifat mekanis bambu Betung pada arah yang lainnya, yaitu arah tegak lurus serat (radial) dan arah perkembangan kulit (tangential). Penelitian ini dilakukan dengan maksud untuk melengkapi data analisis sifat mekanis bambu khususnya Bambu Betung (Dendrocalamus Asper). Selain itu penelitian ini juga untuk mengetahui pengaruhnya terhadap ukuran konstruksi didalamnya. Dari uraian diatas penulis mengambil judul "Analisis Pemodelan Struktur Konstruksi Kapal Ikan Bambu Laminasi Kapasitas 20GT”.

\section{URAIAN PENELITIAN}

Metode yang digunakan dalam penelitian ini adalah metode eksperimen statistik. Metode eksperimen yang dimaksud adalah suatu penelitian yang dilakukan untuk mengetahui suatu akibat yang ditimbulkan dari suatu perlakuan yang diberikan secara sengaja terhadap bambu laminasi dalam pembebanan yang berakibat kepada arah sumbu dari material tersebut pada kondisi sebagai konstruksi kapal ikan. Penulis melakukan eksperimen pengujian kuat tarik dan kuat tekuk, arah untuk pengujian tarik dilakukan dua variasi yaitu arah tangential dan arah radial, sedangkan untuk pengujian tekuk dilakukan satu 
variasi yaitu arah tangential. Studi literatur yang dilakukan adalah yang berkaitan dengan pemahaman teori dan konsep mengenai bambu laminasi Betung sebagai konstruksi pada kapal ikan kapasitas 20GT.

Selain data hasil dari pengujian yang dilakukan oleh penulis, penelitian ini akan menggunakan data penunjang yang diambil sesuai dengan hasil dari penelitian sebelumnya. Data yang dibutuhkan dalam pengerjaan penelitian ini diantaranya hasil pengujian kuat tarik dan tekuk dari bambu Betung, termasuk berat jenis dan karakteristik lainnya. Regulasi yang digunakan dalam menentukan ukuran konstruksi kapal ikan bambu laminasi mengacu pada rule BKI 1996 dan BKI 2013, sehingga aturan yang berkaitan dengan semua perhitungan yang ada mengacu pada regulasi tersebut.

Ukuran utama kapal didapatkan dengan melakukan survei di Paciran, Lamongan, Jawa Timur sebagai acuan kapal ikan kayu dengan kapasitas 20GT. Karena pembangunan kapal ikan ini masih berasaskan kearifan lokal dan bersifat tradisional, maka dalam mendapatkan data untuk lines plan dilakukan pengukuran secara langsung terhadap koordinat-koordinat pada tiap gading yang ada. Proses pengukuran ini dilakukan secara terus-menerus hingga mendapatkan data koordinat dari tiap gading yang ada pada kapal tersebut. Dari data koordinat tersebut selanjutnya akan dilakukan proses redraw menggunakan software AutoCad untuk mendapatkan bentuk body plan, penulis melakukan proses desain kapal ikan menggunakan software Maxsurf Modeler untuk mendapatkan lines plan kapal ikan secara keseluruhan.

Untuk mendapatkan data mekanik bambu laminasi arah lateral, penulis melakukan eksperimen pengujian spesimen bambu laminasi Betung. Pengujian yang dilakukan yaitu pengujian kuat tarik variasi arah radial dan variasi arah tangential. Selain pengujian kuat tarik dilakukan juga pengujian kuat tekuk arah tangential bambu laminasi. Standar yang digunakan dalam pengujian ini yaitu menurut ASTM D3500 untuk uji tarik dan ASTM D3043 untuk uji tekuk [3].

Analisa teknis digunakan pada tahap setelah didapatkan hasil pengujian spesimen. Tahap ini untuk mengetahui apakah kekuatan bambu laminasi arah radial dan arah tangential dari segi kuat tarik dan kuat tekuk memenuhi standar dari BKI. Standar hasil uji tarik dan tekuk minimum yang ditentukan oleh BKI adalah 42,169 MPa utuk uji tarik dan 71,098 MPa untuk uji tekuk [2].

Pada penelitian ini menggunakan studi kasus kapal ikan 20GT. Dalam menentukan ukuran konstruksi kapal tersebut menggunakan rule Biro Klasifikasi Indonesia tahun 2013 tentang "Rules for Small Vessels up to 24m". Ukuran dari konstruksi kapal dipengaruhi oleh jenis bahan laminasi, ukuran lunas, linggi, dan galar balok diberikan tabel dengan angka penunjuk panjang masing-masing elemen konstruksi.

Perhitungan modulus sangat dipengaruhi oleh besarnya beban yang bekerja pada bagian konstruksi tertentu. Pada perhitungan konstruksi kapal kosong, beban yang bekerja diasumsikan sebagai beban luar yang bekerja akibat air laut. Yang mana dibagi menjadi dua, yakni beban lambung dan beban geladak. Masing-masing beban dibagi menjadi bagianbagian yang berbeda sesuai dengan area kerja beban. Beban lambung memiliki area kerja $0,4 \mathrm{~L}$ fore dan after, yang terbagi lagi menjadi dua bagian, yaitu area side dan bottom. Sedangkan beban geladak memiliki area kerja main decki dan deck within cabin/deckhouse. Biasanya hasil perhitungan beban yang terjadi sangat bergantung pada nilai L (panjang konstruksi kapal) karena pada BKI 2013, formula yang digunakan untuk menghitung beban kulit dan geladak menggunakan fungsi $\mathrm{L}$ tersebut. Sehingga semakin besar nilai L maka beban yang diterima oleh kapal akan semakin besar.

Dimensi konstruksi kapal ikan 20GT ditentukan dengan cara menghitung menggunakan rumus empiris dan melihat pada tabel sesuai angka penunjuk hasil perhitungan. Untuk Tebal kulit, geladak dan sekat pada kapal ikan dengan laminasi sebagai material utamanya dapat dihitung menggunakan rumus pendekatan dengan faktor kelengkungan panel pelat, kemudian komponen beban yang bekerja, unsupported span dan ultimate bending strength yang didapat melalui hasil pegujian.

$$
t=0,0452 . f k \cdot b \cdot \sqrt{\frac{P d}{\sigma R M}}
$$

Dengan t merupakan tebal dari konstruksi berbentuk papan pada kapal, sperti kulit dan geladak. Besaran b adalah span atau panjang yang tidak ditumpu oleh bagian konstruksi yang saling berdekatan. Faktor untuk pelat yang dilengkung direpresentasikan dengan fk, dan beban yang bekerja pada komponen konstruksi kapal direpresentasikan dengan Pd. Sedangkan $\sigma_{\mathrm{RM}}$ adalah ultimate bending strength material, yang mana dalam penelitian ini adalah bambu laminasi betung.

Sedangkan ukuran lunas, linggi, dan galar didapat dengan melihat tabel penunjuk. Tabel penunjuk dilihat sesuai dengan panjang L member konstruksi. Dari tabel penunjuk hanya diketahui tinggi dan luas penampang, untuk mendapatkan lebar dapat dicari dengan membagi luas penampang dengan tinggi, tapi sebelumnya luas penampang harus dikalikan dengan faktor pengali yaitu massa jenis material. Faktor pengali didapatkan dari.

$$
k s=\frac{0,056}{\rho}
$$

Rumus tersesebut digunakan apabila massa jenis material tidak sama dengan $0,56 \mathrm{~g} / \mathrm{cm}^{3}$. Faktor pengali tersebut digunakan untuk menentukan lebar dari komponen konstruksi lunas dan linggi. Setelah didapatkan luas maka dikali dengan faktor pengali baru dibagi dengan tinggi yang didapatkan dari tabel angka penunjuk. Dari angka penenjuk tersebut maka didapatkan nilai lebar kali tinggi dari komponen konstruksi. Komponen konstruksi untuk penentuan ukuran lunas, linggi, dan galar memiliki angka penunjuk sendiri-sendiri. Tiga komponen konstruksi ini akan sangat berpengaruh dengan panjang komponen konstruksi. Sedangkan untuk menentukan ukuran dari komponen konstruksi pada wrang, gading kapal ikan dengan material laminasi akan berpengaruh dengan hasil ultimate stress hasil pengujian kuat tarik material. Rumus untuk menghitung gading dan wrang kapal ikan bambu laminasi dapat dilihat pada Tabel 1.

Tabel 1.

\begin{tabular}{|c|c|c|}
\hline \multicolumn{3}{|c|}{$\begin{array}{l}\text { Section moduli of floors and transverse frames of motor, sailing crafts } \\
\text { and motorsailers }\left[\mathrm{cm}^{3}\right]\end{array}$} \\
\hline Floors & Motor craft & $\mathrm{W}_{\mathrm{B}}=3,21 \cdot e \cdot l^{2} \cdot \mathrm{F}_{\mathrm{VF}} \cdot \mathrm{P}_{\mathrm{dBM}} \cdot 10^{-3}$ \\
\hline
\end{tabular}

Perhitungan modulus wrang dan gading 


\begin{tabular}{|c|c|c|}
\hline & & $\mathrm{W}_{\mathrm{Bmin}}=3,21 \cdot e \cdot k_{4}^{2} \cdot l^{2} \cdot \mathrm{F}_{\mathrm{VF}} \cdot \mathrm{P}_{\mathrm{dBM}} \cdot 10^{-3} \geq \mathrm{W}_{\mathrm{S}}$ \\
\hline & $\begin{array}{l}\text { Sailing craft } \\
\text { and motor } \\
\text { sailer }\end{array}$ & $\begin{array}{l}\mathrm{W}_{\mathrm{B}}=2,72 \cdot e \cdot l^{2} \cdot \mathrm{P}_{\mathrm{dBS}} \cdot 10^{-3} \\
\mathrm{~W}_{\mathrm{Bmin}}=2,72 \cdot e \cdot k_{4}{ }^{2} \cdot \mathrm{P}_{\mathrm{dBS}} \cdot 10^{-3} \geq \mathrm{W}_{\mathrm{S}}\end{array}$ \\
\hline \multirow{2}{*}{$\begin{array}{l}\text { Transverse } \\
\text { frames }\end{array}$} & Motor craft & $\begin{array}{l}\mathrm{W}_{\mathrm{S}}=2,18 \cdot e \cdot l^{2} \cdot \mathrm{F}_{\mathrm{SVF}} \cdot \mathrm{P}_{\mathrm{dSM}} \cdot 10^{-3} \\
\mathrm{~W}_{\mathrm{S} \min }=2,18 \cdot e \cdot k_{4}^{2} \cdot \mathrm{F}_{\mathrm{VSF}} \cdot \mathrm{P}_{\mathrm{dSM}} \cdot 10^{-3} \geq L\end{array}$ \\
\hline & $\begin{array}{l}\text { Sailing craft } \\
\text { and motor } \\
\text { sailer }\end{array}$ & $\begin{array}{l}\mathrm{W}_{\mathrm{S}}=2,26 \cdot e \cdot l^{2} \cdot \mathrm{P}_{\mathrm{dSS}} \cdot 10^{-3} \\
\mathrm{~W}_{\mathrm{Smin}}=2,26 \cdot e \cdot k_{4}^{2} \cdot \mathrm{P}_{\mathrm{dSS}} \cdot 10^{-3} \geq L\end{array}$ \\
\hline
\end{tabular}

Hasil perhitungan di atas selanjutnya dikalikan dengan faktor pengali karakteristik material yang didapat dari 152 dibagi dengan ultimate stress hasil dari pengujian spesimen. Rumus faktor pengali tersebut dapat dilihat di bawah ini.

$$
k_{10}=\frac{152}{\sigma_{R m}}
$$

Dalam pemodelan struktur kapal, diperlukan adanya bentuk struktur kapal yang akan dimodelkan. Dalam hal ini model yang digunakan yaitu kapal ikan 20GT di daerah Paciran, Lamongan. Bentuk struktur dari kapal yang dibuat dalam model dasar yang terdiri dari rangkaian geometri yang saling terhubung. Selanjutnya kategori dari material dibuat sebagai persiapan sebelum diterapkan pada geometri yang telah dibuat. Pada pemodelan struktur pemberian kondisi batas (constraint) menjadi bagian yang penting sebelum dilakukan pembebanan karena kondisi batas ini berupa tumpuan yang berguna pada saat proses perhitungan. Setelah proses pembebanan struktur selesai langkah selanjutnya adalah proses solusi pembebanan. Proses ini dilakukan untuk mendapatkan reaksi terhadap pembebanan. Reaksi ini adalah tegangan sisa dan deformasi yang diterima oleh model kapal, nantinya hasil dari simulasi ini akan dibandingkan dengan perhitungan manual yang telah dilakukan. Pemodelan struktur dilakukan dengan menggunakan software MSC Patran 2010, sedangkan untuk metode analisis menggunakan software MSC Nastran 2010 yang bertindak sebagai solver. Software MSC Patran dan Nastran tersebut menggunakan number id 2005vr46.

\section{HASIL DAN PEMBAHASAN}

Analisis yang dilakukan pada penelitian ini terdapat 2 (dua) aspek yang menjadi pertimbangan, pertama adalah aspek hasil dari pengujian spesimen arah lateral (radial dan tangential) dan aspek kekuatan kapal, setelah dilakukan perhitungan secara empiris, dimana hasil analisis dilakukan berdasarkan hasil dari running software dari model kapal ikan kapasitas 20GT.

\section{A. Analisis Teknis Hasil Pengujian}

Pengujian kuat tarik dan kuat tekuk telah dilakukan guna melengkapi data dari sifat mekanik bambu laminasi Betung sebagai material pembangunan kapal ikan bambu laminasi. Pengujian untuk kuat tarik dibuat dua variasi, yaitu variasi arah tangential dan arah radial, sedangkan untuk uji kuat tekuk dengan variasi arah tangential. Hasil dari perhitungan pengujian perlu dilakukan analisis teknis guna mengetahui apakah bambu laminasi Betung dari segi kuat tarik dan kuat tekuk memenuhi syarat minimum yang telah ditentukan oleh BKI sebagai material yang akan digunakan sebagai konstruksi kapal.
Tabel 2.

Analisis hasil uji tarik (tensile strength)

\begin{tabular}{|c|c|c|c|c|c|c|}
\hline \multirow{3}{*}{$\begin{array}{c}\text { Nomer } \\
\text { Spesimen }\end{array}$} & \multicolumn{6}{|c|}{ "Hasil Pengujian } \\
\hline & \multicolumn{3}{|c|}{ Variasi Tangential } & \multicolumn{3}{|c|}{ Variasi Radial } \\
\hline & $\begin{array}{c}\text { Tegangan } \\
(\mathrm{MPa})\end{array}$ & $\begin{array}{l}\mathrm{MoE} \\
(\mathrm{GPa})\end{array}$ & $\begin{array}{c}\text { Strain } \\
(\%)\end{array}$ & $\begin{array}{c}\text { Tegangan } \\
(\mathrm{MPa})\end{array}$ & $\begin{array}{l}\mathrm{MoE} \\
(\mathrm{GPa})\end{array}$ & $\begin{array}{c}\text { Strain } \\
(\%)\end{array}$ \\
\hline 1 & 61,51 & 18,00 & 21,88 & 51,28 & 15,11 & 21,72 \\
\hline 2 & 64,06 & 18,10 & 22,66 & 54,79 & 16,62 & 21,09 \\
\hline 3 & 66,87 & 19,15 & 22,34 & 54,13 & 15,51 & 22,34 \\
\hline 4 & 68,60 & 18,99 & 23,13 & 41,77 & 13,37 & 20,00 \\
\hline 5 & 66,94 & 19,31 & 22,19 & 53,76 & 17,07 & 20,156 \\
\hline Rata-rata & 65,60 & 18,71 & 22,44 & 51,15 & 15,53 & 21,06 \\
\hline
\end{tabular}

Dari Tabel 2 dapat diketahui bahwa kuat tarik bambu lamina arah tangential lebih besar dari pada arah radial. Pada arah tangential memiliki nilai kuat tarik sebesar 65,60 MPa, nilai MoE sebesar 18,71 GPa, dan nilai strain sebesar 22,44\%. Sedangkan pada arah radial nilai kuat tarik sebesar 51,15 MPa, nilai MoE sebesar 15,53 GPa, dan nilai strain sebesar 21,06\%. Tabel 3.

\begin{tabular}{cccc}
\multicolumn{3}{c}{ Analisis hasil uji tekuk (bending strength) } \\
\hline \hline \multirow{2}{*}{$\begin{array}{c}\text { Nomer } \\
\text { Spesimen }\end{array}$} & $\begin{array}{c}\text { MoR } \\
\text { (MPa) }\end{array}$ & $\begin{array}{c}\text { MoE } \\
\text { (GPa) }\end{array}$ & $\begin{array}{c}\text { Defleksi } \\
\text { (mm) }\end{array}$ \\
\hline 1 & 144,89 & 12,89 & 17,7 \\
2 & 118,25 & 13,84 & 13,4 \\
3 & 122,19 & 14,19 & 13,3 \\
4 & 143,25 & 15,50 & 14,2 \\
5 & 125,52 & 13,14 & 14,7 \\
Rata-rata & 124,95 & 13,7 & 14,12 \\
\hline \hline
\end{tabular}

Sedangkan pada Tabel 3 memperlihatkan hasil pengujian kuat tekuk didapatkan sebagai berikut, nilai kuat tekuk sebesar 124,95 MPa, nilai MoE sebesar 13,7 GPa, dan nilai defleksi sebesar 14,12 mm.

Jenis bambu varietas Bambusa Arundinacea yang berumur lebih dari 3 tahun. Kekuatan lentur bambu laminasi diuji dengan menggunakan Standar ASTM D3043, hasil pengujian ini menunjukkan bahwa kekuatan lentur nilai MOR dan MOE masing-masing 84,12 MPa dan 18,04 GPa [3]. Sedangkan jenis bambu varieatas Dendrocalamus Asper dengan umur bambu lebih dari 3 tahun. Memiliki kekuatan lentur yang tidak jauh beda dengan jenis varietas Bambusa Arundinacea, yaitu ditunjukkan bahwa kekuatan lentur nilai MOR dan MOE masing-masing $80 \mathrm{MPa}$ dan 17,54 GPa [4].

Menurut peraturan dari BKI tahun 2013 tentang "'Rules for Small Vessels up to $24 \mathrm{~m}$ ", menyebutkan bahwa laminasi yang akan digunakan sebagai material konstruksi harus memiliki nilai kuat tarik minimum 42,169 MPa. Nilai bending strength minimum yang disyaratkan oleh BKI adalah sebesar 71,098 MPa. Dari hasil pengujian kuat tarik dan kuat tekuk pada arah radial, tangential (untuk kuat tarik) dan arah tangential (untuk kuat tekuk) bambu laminasi Betung tersebut memenuhi syarat minimum BKI sebagai material konstruksi kapal ikan.

\section{B. Perhitungan Ukuran Konstruksi}

Perhitungan ukuran komponen konstruksi kapal ikan 20GT didapatkan dari hasil perhitungan menggunakan rumus empiris menurut rule BKI 2013 tentang "Rules for Small Vessels up to $24 m$ ". Survei yang telah dilakukan oleh penulis guna mendapatkan data mengenai model kapal ikan kapasaitas 20GT menghasilkan ukuran utama kapal dan rencana garis (lines plan) dari bentuk kapal ikan yang berada di Paciran, Lamongan. Ukuran utama kapal ikan 20 GT sebagai berikut. 
Panjang kapal (Loa) : 12 meter

Panjang garis air $(\mathrm{Lwl}) \quad: 11,4$ meter

Lebar kapal (B) : : 4 meter

Tinggi Kapal $(\mathrm{H}) \quad:$ : 4,4 meter

Sarat $(\mathrm{T}) \quad: 1,6$ meter

Kecepatan (Vs) : 7 knot

Dari hasil survei tersebut juga didapatkan rencana garis (lines plan). Lines plan didapatkan dari hasil pengukuran tiap gading kapal dengan mengambil sebanyak 4 titik. Hasil dari redraw tersebut akan menghasilkan lines plan kapal ikan yang dimaksud. Rencana gari (lines plan) kapal ikan yang telah dibuat dapat dilihat pada Gambar 1.
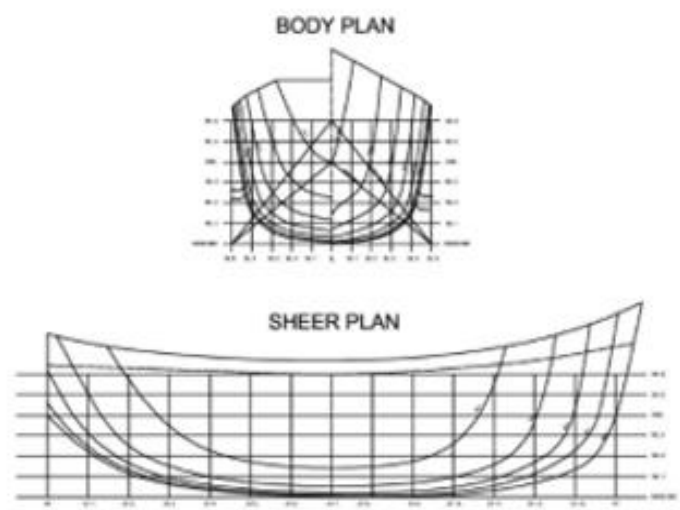

HALF BREADTH PLAN



Gambar 1. Lines plan kapal ikan kapasitas 20GT di daerah Paciran, Lamongan.

Perhitungan ukuran komponen konstruksi kapal didapatkan setelah melakukan perhitungan menggunakan rumus empiris. Hasil dari perhitungan tersebut dapat dilihat pada Tabel 4 .

Tabel 4.

Ukuran konstruksi kapal ikan bambu laminasi 20GT

\begin{tabular}{|l|c|c|c|}
\hline \multirow{2}{*}{ Bagian Konstruksi } & \multicolumn{3}{|c|}{ Bambu Laminasi Betung } \\
\cline { 2 - 4 } & lebar (mm) & tinggi $(\mathrm{mm})$ & luas $\left(\mathrm{mm}^{2}\right)$ \\
\hline Lunas & 90 & 165 & 148,396 \\
\hline linggi haluan & 60 & 98 & 58,577 \\
\hline Gading & 40 & 62 & 24,693 \\
\hline Wrang & 40 & 68 & 27,007 \\
\hline galar balok & 60 & 78 & 46,862 \\
\hline galar kim & 60 & 78 & 46,862 \\
\hline balok geladak & 90 & 78 & 69,794 \\
\hline \multicolumn{2}{|c|}{ Bagian Konstruksi } & \multicolumn{2}{|c|}{ tebal (mm) } \\
\hline Kulit sisi lambung & \multicolumn{2}{|c|}{20} \\
\hline Kulit bawah lambung & \multicolumn{2}{c|}{11} \\
\hline Kulit geladak & \multicolumn{2}{c|}{20} \\
\hline Kulit bangunan atas & \multicolumn{2}{|c|}{} \\
\hline Kulit sekat & & \multicolumn{3}{|c|}{} \\
\hline
\end{tabular}

\section{Analisis Distribusi Tegangan}

Analisis untuk mengetahui distribusi tegangan yang terjadi pada model kapal dibantu dengan komputer. Hasil running model ditunjukan dengan bentuk kapal dengan warna-warna pada daerah lambung. Warna tersebut menunjukkan tegangan yang terjadi pada elemen tertentu dalam suatu area. Semakin gelap warna, maka semakin besar pula nilai tegangan yang ditunjukkan, begitu sebaliknya. Tegangan yang tertera pada hasil analisis running menggunakan satuan $\mathrm{Pa}$ atau $\mathrm{N} / \mathrm{m}^{2}$. Tinjauan analisis kekuatan kapal pada AP hingga $0,25 \mathrm{~L}$ dari midship kapal, karena sepanjang area tersebut mengalami momen terbesar tegangan terbesar [5].

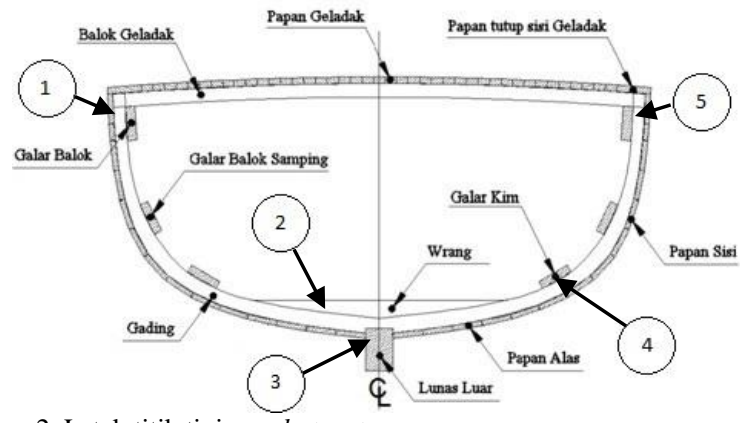

Gambar 2. Letak titik tinjauan hotspot area

Letak tinjauan analisis pada kapal ikan ditunjukkan pada Gambar 2. Sambungan 1: sambungan antara balok geladak, gading, dan kulit; sambungan 2: sambungan antara wrang dengan gading; sambugan 3: sambungan antara lunas, kulit, gading dan wrang; sambungan 4: sambungan antara galar kim dengan gading; sambungan 5: sambungan antara galar balok dengan gading.

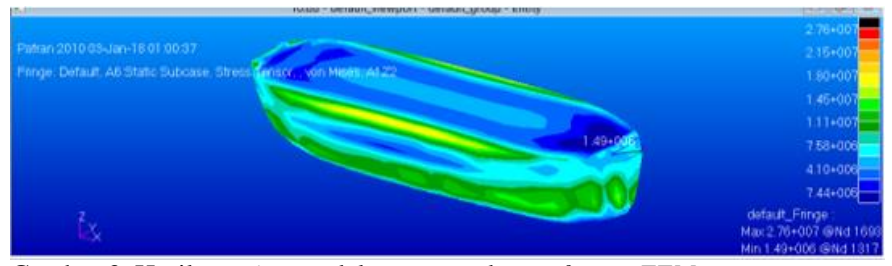

Gambar 3. Hasil running model menggunakan software FEM

Pada Gambar 3 dapat dilihat hasil running model yang memperlihatkan distribusi tegangan yang diterima oleh kapal ikan bambu laminasi kapasitas 20GT. Dari gambar tersebut dapat dilihat apabila warna yang terdapat pada model semakin gelap maka dapat disimpulkan bahwa beban yang diterima semakin besar. Hasil distribusi tegangan yang diterima oleh badan kapal akan dibandingkan dengan tegangan ijin..

Tabel 5.

Distribusi tegangan yang diterima oleh kapal

\begin{tabular}{|c|c|c|c|c|c|c|c|}
\hline \multirow{3}{*}{$\begin{array}{c}\text { No. } \\
1\end{array}$} & \multirow{3}{*}{$\begin{array}{c}\begin{array}{c}\text { Nomer } \\
\text { Frame }\end{array} \\
1-4\end{array}$} & \multicolumn{6}{|c|}{ Nilai Tegangan } \\
\hline & & \multicolumn{2}{|c|}{ Deck } & \multicolumn{2}{|c|}{ Side Shell } & \multicolumn{2}{|c|}{ Bottom } \\
\hline & & 16,40 & Мра & 16,90 & Mpa & 27,60 & Мра \\
\hline 2 & $4-8$ & 18,80 & Мра & 19,60 & Мpa & 15,40 & Мра \\
\hline 3 & $8-12$ & 20,70 & Mpa & 20,00 & Mpa & 14,40 & Mpa \\
\hline 4 & $12-16$ & 19,90 & Мра & 19,90 & Mpa & 14,70 & Мpa \\
\hline 5 & $16-20$ & 16,10 & Мра & 19,00 & Мpa & 16,20 & Мра \\
\hline 6 & $20-24$ & 11,10 & Мpa & 15,40 & Мpa & 17,80 & Мра \\
\hline Nila & simum & 20,70 & Mpa & 20,00 & Mpa & 27,60 & $\mathrm{Mpa}$ \\
\hline
\end{tabular}

Pada Tabel 5 dapat dilihat hasil pengamatan pada bagian geladak, side shell, dan bottom. Hasil tersebut adalah kondisi tegangan yang diterima oleh kapal ikan bambu laminasi. Tegangan tertinggi yang diterima oleh kapal adalah sebesar 27,60 MPa, kondisi tersebut terletak pada bagian buritan kapal. Pengamatan hotspot area dilakukan untuk mengetahui tegangan pada titik kritis dalam hal ini yang dimaksudkan adalah pada 
bagian sambungan kompoonen konstruksi. Hasil pengamatan analisa hotspot area dapat dilihat pada Tabel 6.

Tabel 6.

Nilai tegangan pada hotspot area

\begin{tabular}{|c|c|c|c|c|c|}
\hline \multirow{2}{*}{$\begin{array}{c}\text { Nomer } \\
\text { Gading }\end{array}$} & \multicolumn{5}{|c|}{ Hotspot } \\
\cline { 2 - 6 } Gading 0 & $1,37 \mathrm{Mpa}$ & $2,97 \mathrm{Mpa}$ & $2,65 \mathrm{Mpa}$ & $8,00 \mathrm{Mpa}$ & $4,90 \mathrm{Mpa}$ \\
\hline Gading 1 & $5,70 \mathrm{Mpa}$ & $10,5 \mathrm{Mpa}$ & $8,04 \mathrm{Mpa}$ & $7,65 \mathrm{Mpa}$ & $1,35 \mathrm{Mpa}$ \\
\hline Gading 2 & $8,53 \mathrm{Mpa}$ & $9,02 \mathrm{Mpa}$ & $2,99 \mathrm{Mpa}$ & $7,43 \mathrm{Mpa}$ & $1,46 \mathrm{Mpa}$ \\
\hline Gading 3 & $13,04 \mathrm{Mpa}$ & $3,65 \mathrm{Mpa}$ & $6,77 \mathrm{Mpa}$ & $0,27 \mathrm{Mpa}$ & $2,02 \mathrm{Mpa}$ \\
\hline Gading 4 & $14,41 \mathrm{Mpa}$ & $1,35 \mathrm{Mpa}$ & $1,27 \mathrm{Mpa}$ & $4,20 \mathrm{Mpa}$ & $4,19 \mathrm{Mpa}$ \\
\hline Gading 5 & $15,39 \mathrm{Mpa}$ & $2,14 \mathrm{Mpa}$ & $9,78 \mathrm{Mpa}$ & $2,69 \mathrm{Mpa}$ & $6,58 \mathrm{Mpa}$ \\
\hline Gading 6 & $15,50 \mathrm{Mpa}$ & $0,57 \mathrm{Mpa}$ & $8,16 \mathrm{Mpa}$ & $6,34 \mathrm{Mpa}$ & $6,24 \mathrm{Mpa}$ \\
\hline Gading 7 & $16,44 \mathrm{Mpa}$ & $0,15 \mathrm{Mpa}$ & $2,27 \mathrm{Mpa}$ & $5,20 \mathrm{Mpa}$ & $6,27 \mathrm{Mpa}$ \\
\hline Gading 8 & $16,81 \mathrm{Mpa}$ & $4,62 \mathrm{Mpa}$ & $2,03 \mathrm{Mpa}$ & $3,85 \mathrm{Mpa}$ & $3,51 \mathrm{Mpa}$ \\
\hline Gading 9 & $16,84 \mathrm{Mpa}$ & $4,66 \mathrm{Mpa}$ & $7,79 \mathrm{Mpa}$ & $1,04 \mathrm{Mpa}$ & $1,90 \mathrm{Mpa}$ \\
\hline Gading 10 & $16,86 \mathrm{Mpa}$ & $3,69 \mathrm{Mpa}$ & $6,15 \mathrm{Mpa}$ & $1,86 \mathrm{Mpa}$ & $0,59 \mathrm{Mpa}$ \\
\hline Gading 11 & $16,56 \mathrm{Mpa}$ & $2,25 \mathrm{Mpa}$ & $4,25 \mathrm{Mpa}$ & $4,61 \mathrm{Mpa}$ & $6,02 \mathrm{Mpa}$ \\
\hline Gading 12 & $16,49 \mathrm{Mpa}$ & $2,62 \mathrm{Mpa}$ & $4,91 \mathrm{Mpa}$ & $3,15 \mathrm{Mpa}$ & $6,64 \mathrm{Mpa}$ \\
\hline Gading 13 & $16,73 \mathrm{Mpa}$ & $2,96 \mathrm{Mpa}$ & $3,02 \mathrm{Mpa}$ & $2,91 \mathrm{Mpa}$ & $0,30 \mathrm{Mpa}$ \\
\hline Gading 14 & $16,48 \mathrm{Mpa}$ & $2,83 \mathrm{Mpa}$ & $4,76 \mathrm{Mpa}$ & $1,48 \mathrm{Mpa}$ & $5,92 \mathrm{Mpa}$ \\
\hline Gading 15 & $15,71 \mathrm{Mpa}$ & $0,18 \mathrm{Mpa}$ & $0,39 \mathrm{Mpa}$ & $5,16 \mathrm{Mpa}$ & $6,58 \mathrm{Mpa}$ \\
\hline Gading 16 & $16,63 \mathrm{Mpa}$ & $0,97 \mathrm{Mpa}$ & $0,73 \mathrm{Mpa}$ & $2,82 \mathrm{Mpa}$ & $1,44 \mathrm{Mpa}$ \\
\hline Gading 17 & $15,24 \mathrm{Mpa}$ & $0,88 \mathrm{Mpa}$ & $3,24 \mathrm{Mpa}$ & $1,23 \mathrm{Mpa}$ & $4,21 \mathrm{Mpa}$ \\
\hline Gading 18 & $13,89 \mathrm{Mpa}$ & $1,00 \mathrm{Mpa}$ & $2,04 \mathrm{Mpa}$ & $0,67 \mathrm{Mpa}$ & $2,73 \mathrm{Mpa}$ \\
\hline Gading 19 & $13,62 \mathrm{Mpa}$ & $5,13 \mathrm{Mpa}$ & $3,76 \mathrm{Mpa}$ & $1,82 \mathrm{Mpa}$ & $2,44 \mathrm{Mpa}$ \\
\hline Gading 20 & $12,37 \mathrm{Mpa}$ & $7,02 \mathrm{Mpa}$ & $8.05 \mathrm{Mpa}$ & $0,45 \mathrm{Mpa}$ & $2,90 \mathrm{Mpa}$ \\
\hline Gading 21 & $10,74 \mathrm{Mpa}$ & $3,05 \mathrm{Mpa}$ & $3,36 \mathrm{Mpa}$ & $0,60 \mathrm{Mpa}$ & $0,05 \mathrm{Mpa}$ \\
\hline Gading 22 & $8,87 \mathrm{Mpa}$ & $8,29 \mathrm{Mpa}$ & $2,51 \mathrm{Mpa}$ & $8,05 \mathrm{Mpa}$ & $3,83 \mathrm{Mpa}$ \\
\hline Gading 23 & $5,12 \mathrm{Mpa}$ & $10,6 \mathrm{Mpa}$ & $5,56 \mathrm{Mpa}$ & $7,45 \mathrm{Mpa}$ & $3,92 \mathrm{Mpa}$ \\
\hline Maksimum & $16,86 \mathrm{Mpa}$ & $10,6 \mathrm{Mpa}$ & $9,78 \mathrm{Mpa}$ & $7,45 \mathrm{Mpa}$ & $3,92 \mathrm{Mpa}$ \\
\hline
\end{tabular}

Distribusi tegangan yang diterima oleh kapal didapatkan dari pembebanan yang disesuaikan dengan bentuk atau arah pada komponen konstruksi. Kondisi tersebut dapat menjelaskan karena bambu laminasi merupakan jenis material ortrotopik. Kondisi beban yang diterima oleh material tidak sepenuhnya disebarkan secara merata sesuai dengan arah serat dan laminasi pada material bambu tersebut. Pada Tabel 6 dapat dilihat tegangan tertinggi yang didapat pada pengamatan hotspot area sebesar 16,86 MPa pada sambungan balok geladak dan gading. Sedangkan tegangan terendah yang didapatkan pada hotspot hanya 3,92 MPa pada sambungan galar balok dengan gading.

Kapal ikan bambu laminasi Betung memenuhi kriteria kekuatan konstruksi sesuai dengan arah bambu laminasi, yaitu arah longitudinal, arah radial, dan arah tangential. Hal ini berdasarkan hasil pengamatan pada hotspot area dan kondisi keseluruhan yang diterima oleh kapal menunjukkan tegangan maksimum yang diterima oleh kapal bambu laminasi Betung untuk kapasitas 20GT sebesar 27,60 MPa tidak melebihi tegangan izin yang telah ditentukan. Tegangan izin tarik pada bambu laminasi Betung sebesar $112 \mathrm{MPa}$ arah longitudinal. Tegangan izin tekuk pada bambu laminasi Betung sebesar 64 MPa arah radial.

\section{KESIMPULAN/RINGKASAN}

Berdasarkan hasil pengujian, perhitungan dan analisa yang telah dilakukan pada pengerjaan penelitian ini, maka dapat ditarik kesimpulan sebagai berikut:

1. Secara teknis, ditinjau dari hasil pengujian kuat tarik, bambu Betung laminasi variasi arah tangential memiliki nilai kuat tarik sebesar 65,60 MPa dan bambu Betung laminasi variasi arah radial memiliki nilai kuat tarik sebesar 51,15 MPa, hasil uji tersebut dapat dikatakan masih memenuhi standar minimal Biro Klasifikasi Indonesia yaitu lebih dari 42,169 MPa. Sedangkan untuk kuat tekuk variasi arah tangential sebesar 124,95 MPa, hasil uji ini juga masih memenuhi standar minimal Biro Klasifikasi Indonesia yaitu lebih dari 71,098 MPa.

2. Dimensi lebar dan tebal lunas, gading, balok geladak, dan kulit berbahan bambu laminasi yang didapat dari hasil perhitungan menggunakan acuan rule Biro Klasifikasi Indonesia 2013 didapatkan. lunas 90x165 mm, gading 40x62 mm, balok geladak 90x78 mm, dan kulit dengan ketebalan $20 \mathrm{~mm}$.

3. Hasil identifikasi pemodelan struktur menggunakan software FEM menunjukkan pada pengamatan hotspot didapatkan tegangan (stress) terbesar 27,60 MPa pada bagian dasar (bottom) di buritan kapal, hasil tersebut membuktikan bahwa material bambu laminasi Betung memenuhi dalam aspek kekuatan kapal ikan kapasitas 20GT. Yakni tegangan maksimum pada kapal tidak lebih dari 112 MPa untuk kuat tarik dan 64 MPa untuk kuat tekuk.

\section{UCAPAN TERIMA KASIH}

Penulis mengucapkan terima kasih, yang pertama kepada Bapak Dr. Ir. Heri Supomo, M.Sc. selaku dosen pembimbing. Kedua kepada Ayah dan Ibu yang telah memberikan dukungan doa dan biaya demi terselesaikannya penelitian ini. Ketiga kepada teman-teman dan pihak-pihak yang tidak dapat Penulis sebutkan satu per satu.

\section{DAFTAR PUSTAKA}

[1] B. K. Indonesia, Rule for Small Fishing Vessels up to $24 \mathrm{~m}$. Jakarta: Biro Klasifikasi Indonesia (BKI), 2013.

[2] B. K. Indonesia, Buku Peraturan Klasifikasi dan Konstruksi Kapal Kayu. Jakarta: Biro Klasifikasi Indonesia, 1996.

[3] A. Supomo, H., Manfaat, D., \& Zubaydi, "Flexural Strenght Analysis of Laminated Bamboo Slats (Bambusa Arundinacea) for Constructing a Small Fishing Boat Shells," Int. J. Small Cr. Technol., 205AD.

[4] H. Supomo, "Studi Penggunaan Bambu Sebagai Material Alternatif untuk Bahan Pembuatan Kapal Ikan dengan Metode Cold Press Planking System," ITS, 2016.

[5] ABS, Guidance Notes On Reliability Centered Maintenance. American Bureau of Shipping, 2004. 